\title{
Hypothyroidism and stunting around the Merapi Volcano
}

\author{
Pramudji Hastuti*, Ahmad Hamim Sadewa, Prasetyastuti, Sunarti, Arta Farmawati, Ngadikun, \\ Dianandha Septiana Rubi, Abrory Agus Cahya Pramana
}

Department of Biochemistry, Faculty of Medicine, Public Health, and Nursing, Universitas Gadjah Mada, Yogyakarta, Indonesia

KEYWORDS Hypothyroidism lodine

Stunting

TSH levels

Triiodothyronine

\begin{abstract}
Cangkringan is a mountainous area with the possibility of low iodine sources in the soil. Additionally, Cangkringan area is the area nearest to where eruptions of Merapi mountain have occurred, which further could reduce iodine levels in the soil. This study examined the incidence of hypothyroidism due to iodine deficiency and potential links to stunting events on the slopes of Merapi mountain. By using ELISA methods, a total of 94 mothers were tested to detect the triiodothyronine (T3) and thyroid-stimulating hormone (TSH) levels to determine the status of hypothyroidism, while 94 children were assessed to check the stunting rates by measuring height compared to age. We found hypothyroidism was $3(3.2 \%)$ out of 94 mothers examined and $30(31.9 \%)$ out of 94 children examined were stunted $(19.1 \%$ short stature and $12.8 \%$ very short stature). There was a significant difference between the mothers' TSH levels among very short stature and normal stature. We concluded that hypothyroidism in mothers is correlated with stunting children in Cangkringan, Sleman sub-district. Further research is needed to determine the frequency of hypothyroidism and stunting in other slopes of Merapi mountain, where the low-iodine soil composition is potentially related to hypothyroidism and stunting incidence. Thus, further treatment is needed by local health staff and governments to address the negative effects of hypothyroidism and stunting.
\end{abstract}

(C) The Journal 2021. This article is distributed under a Creative Commons Attribution-ShareAlike 4.0 International license.

\section{Introduction}

Hypothyroidism occurs when not enough thyroid hormones are produced. The thyroid is a small butterfly-shaped gland located at the front of neck. This gland secretes hormones that help the body regulate and use energy. It also controls the function of some organs to work properly. Low thyroid hormones can cause the body's natural function to slow down. Hypothyroidism is more common in women than in men ${ }^{1}$. Cangkringan, a sub-district in Sleman Regency, Yogyakarta Province, is located in the highlands and hills where Merapi Volcano eruptions periodically happen and it affects the content of soil mineral sources, especially iodine levels. lodine deficiency in the soil is widely found in inland areas, in mountainous areas, and flooded areas. ${ }^{2}$ The high incidence of worldwide hypothyroidism is caused

\footnotetext{
*Correspondence: pramudji.has@ugm.ac.id

Department of Biochemistry, Faculty of Medicine, Public Health and Nursing, Universitas Gadjah Mada, Jl. Farmako, Sekip Utara, Yogyakarta 55281, Indonesia
}

by a lack of iodine in the diet. That condition is a public health problem in many countries. ${ }^{3}$ Data of primary health research in 2007 in Indonesia based on examination of the thyroid-stimulating hormone (TSH) level found that 2.7 percent of men and 2.2 percent of women had high TSH levels as an indicator of hypothyroidism. ${ }^{4}$ Stunting is a disorder in children's growth and development caused by inhibition of height, which is inappropriate with their age. Stunting is a chronic nutritional problem involving insufficient nutritional intake, recurrent infections, and low birth height. The prevalence of children with stunting in Indonesia based on basic health research in 2018 is $\mathbf{3 0 . 8 \%}$ and in Central Java it also found the prevalence was more than $30 \%$. The condition of the mother before and during pregnancy affects the occurrence of stunting. Stunting is caused by genetics, socioeconomic factors, history of mothers with malnutrition (deficiency of protein and minerals) during pregnancy and lactation, and history of low birth weight. ${ }^{5}$ Stunting usually starts from the age of 3 months, and gradually slows down by 3 years 
of age. Measurements of height per age or weight per age could be used to detect the occurrence of stunting. ${ }^{6}$ Hypothyroidism in the mother during pregnancy, infancy, or childhood phases also can cause stunting. ${ }^{7}$ In this study, we detected the occurrence of hypothyroidism in some mothers and associated it with stunting in children in Cangkringan area.

\section{Method}

This research was a descriptive observational study, and we examined 94 mothers and their children from Cangkringan, Sleman, Yogyakarta. Subjects were mothers and children who came to health services in three villages in Cangkringan. Sampling was done by consecutive random sampling. Subjects were healthy mothers and their children. Subjects were excluded if there were chronic diseases identified from interviews and medical examinations.

The number of samples was determined with the Lemeshow calculation, using the hypothyroid mother's frequency in Indonesia, which was $2.2 \%$, and the significance was $5 \%$; the minimum sample was 33. Calculation of the sample number with stunting frequency which was $30 \%$ and the significance was $10 \%$, so the minimum number of samples was 56 . Samples were taken in July-September 2019. Samples from the mothers were examined to determine the TSH levels and triiodothyronine (T3) in their blood with ELISA methods. Children were measured for weight, and length/height with standardized scales, and stature meter.

Three millimeters of maternal blood were taken and inserted into EDTA tube. Blood was separated between the blood cells and the plasma. Plasma was used for detecting TSH and T3 levels. Hypothyroidism was identified if the TSH level is $<2.5 \mathrm{MIU} / \mathrm{L} 6$ or the T3 level is $<0.9 \mathrm{mmol} / \mathrm{L} .{ }^{8}$ Children were identified as stunting after results of height $(\mathrm{cm})$ were compared with their age (month) by the IDAI chart ${ }^{9}$ and having a $\mathrm{Z}$ score of <-2 standard deviation (SD) for short stature and $<-3 S D$ for very short.

Data normality was analyzed using GraphPad 9.0, then the concentration of mothers' TSH and T3 levels was correlated with their child's status to determine the effect of hypothyroidism with stunting incidence. Data were analyzed with analysis of variance and the results were significantly different if $P<0.05$. For undistributed normally data, Kruskal-Wallis test was used to analyze the variance. All subjects had signed informed consent for their willingness to participate in this study. This research has received ethics approval from the Medical and Health Research Ethics Committee of the Faculty of Medicine, Public Health and Nursing, Yogyakarta, Indonesia.

\section{Result}

The study involved a total of 94 mothers and their children taken from three villages in Cangkringan. The subjects' characteristics are shown in Table 1.

Table 1 shows three mothers (3.2\%) had hypothyroidism with a higher TSH level and $31.9 \%$ of the children examined with short stature were $19.1 \%$, and very short stature were $12.8 \%$. Correlations of T3 and TSH levels with stature group (normal, short, and very short stature) are shown in Table 2.

Based on the data obtained, normal T3 and TSH levels were not distributed normally $(P<0.0001)$.

Table 1. Characteristics of subjects from Cangkringan, Sleman, Yogyakarta

\begin{tabular}{lll}
\hline & Mothers $(\mathbf{n}=94)$ & Children $(\mathbf{n}=94)$ \\
\hline Age & $31.2 \pm 7.0(\mathrm{yr})$ & $39.5 \pm 15.8(\mathrm{mo})$ \\
Body weight & $68.0 \pm 48.5(\mathrm{~kg})$ & $14.3 \pm 15.6(\mathrm{~g})$ \\
Height $(\mathrm{cm})$ & $152.17 \pm 4.9$ & $81.2 \pm 14.5$ \\
T3 concentration (mmol/L) & $1.11 \pm 0.196$ & \\
TSH concentration ( $\mu \mathrm{lU} / \mathrm{L})$ & $1.05 \pm 0.478$ & \\
Hypothyroidism frequency & $3(3.2 \%)$ & $30(31.9 \%)$ \\
$\quad$ & & $18(19.1 \%)$ \\
$\quad$ stunting frequency & & $12(12.8 \%)$ \\
\hline
\end{tabular}


Table 2. The correlation of TSH and T3 level of mothers with their children's stature

\begin{tabular}{lll}
\hline & $\begin{array}{l}\text { T3 } \\
(\mathbf{m m o l} / \mathrm{L})\end{array}$ & $\begin{array}{l}\text { TSH } \\
(\mu \mathrm{lU} / \mathrm{L})\end{array}$ \\
\hline Normal $(\mathrm{n}=64)$ & $1.60 \pm 1.04$ & $1.03 \pm 0.72^{*}$ \\
Short $(\mathrm{n}=18)$ & $1.44 \pm 0.38$ & $0.98 \pm 0.58$ \\
Very short $(\mathrm{n}=12)$ & $1.39 \pm 0.35$ & $1.66 \pm 1.03^{*}$ \\
$p$ & 0.673 & $0.002^{*}$ \\
\hline *showed significantly difference was obtained with $\mathrm{P}<0.05$
\end{tabular}

Meanwhile, short T3 and TSH data were distributed normally ( $P=0.07$ and 0.17 , respectively). Meanwhile, very short T3 data were distributed normally $(P=0.34)$ but very short TSH data were not distributed normally $(P=0.0004)$. It was found that there was no difference in the level of T3 in all group statures. However, if the highest TSH level was found in the very short stature, compared to the other statures in the TSH group, this level was significantly different from the normal group ( $P=0.002$ ).

\section{Discussion}

This study was conducted to determine the occurrence of hypothyroidism in enrolled mothers and was associated with stunting in children from Cangkringan sub-district, Sleman. Hypothyroid condition of the mother before and during pregnancy affects fetal growth, causing low birth weight and stunting the child's growth. This study showed that there were $3.2 \%$ of mothers who had hypothyroidism and $31.9 \%$ of children with stunting $(19.1 \%$ short stature and $12.8 \%$ very short stature). This study found no correlation between the level of T3 and TSH identified in the mothers and the occurrence of stunting in the children, but it was found that very short stature had a high level of TSH, and this level was significantly different with normal stature. This study suggested that the occurrence of stunting with short stature may cause an abnormal level of TSH, and contribute to malnutrition in children during their growth, while for children with very short stature it was correlated with hypothyroidism of their mother. Nationally, stunting in Indonesia was $37 \%$ in 2013 and this decreased to $27.6 \%$ in 2019. ${ }^{10}$ In the Cangkringan sub-district, the stunting was $31.9 \%$. This finding indicates that this figure is higher than the national frequency and may be because the iodine source in the soil is low in Cangkringan as occurs in many mountainous areas.

This study found hypothyroidism in $3.2 \%$ of the 97 mothers examined. This finding is still relatively high compared to the world of $0.5 \%$ and in Indonesia, $2.2 \%{ }^{4}$ This condition may be caused by the lower iodine source in the soil. In endemic areas, the prevalence of hypothyroidism is 5 per 1,000, while the prevalence of subclinical hypothyroidism is 15 per 1,000 . Hypothyroidism generally occurs in women, with the incidence rate of primary hypothyroidism in America of 3.5 per 1,000 inhabitants for women and 0.6 per 1,000 inhabitants for men. ${ }^{11}$ Cangkringan is in the highlands where the eruption of Merapi mountain occurs periodically, which will affect the source of soil minerals especially iodine levels. It is thought that iodine deficiency is still high in Cangkringan. lodine is an essential trace element necessary for thyroid hormone synthesis. lodine deficiency is the most common cause of neonatal brain damage and development of children's mental disability worldwide. ${ }^{12}$ lodine, as iodide forms in oceans, enters the atmosphere, falls into the earth by rain, and goes into the ground. lodine deficiency in the soil is widely found in inland areas, mountainous areas, and flooded areas..$^{13}$ The causes of hypothyroidism vary, such as autoimmune, hyperthyroidism treatment, radiation therapy, the treatment that decreases thyroid hormone production, and iodine deficiency. ${ }^{1}$

Low iodine is mostly found in the remote areas on the mountain slopes in the areas often affected by flooding. ${ }^{13}$ The thyroid hormone influences several organ systems, and as a result, the symptoms of hypothyroidism are varied. There is no special diet to treat this disease, but the affected individual should follow a balanced diet with a variety of foods that are not high in fat and sodium. It is considered better to reduce or avoid the local foods grown in soil-deficient areas and those that are identified to be low in iodine. There are several natural sources of iodine-bound supplements which are considered beneficial for hypothyroidism, such as seleniumrich, vitamin $D$ containing probiotic foods including kelp, kefir/yogurt, and various types of fruits and vegetables. ${ }^{14}$

Stunting is a chronic nutritional problem that 
involves insufficient nutritional intake, recurrent infections, and low birth weight. The condition of the mother before and during pregnancy is related to the occurrence of stunting. ${ }^{15}$ Stunting interferes with the brain development and metabolism of the body. Stunting also causes delays in physical growth. Delayed brain development causes a child to have lower intelligence below the average of their age. Stunting also decreases the immune system's response. This condition causes children to become sick easily. ${ }^{16}$ Malnutrition can start while the child is still a fetus until two years. Protein deficiency is the most common cause of stunting. Deficiency of minerals such as iron, copper, calcium and iodine also causes the child to not grow optimally. Infection due to poor environmental hygiene can also be a cause of stunting. ${ }^{17}$ Lack of female empowerment and declining environmental quality are also some of the contributing causes of stunting. ${ }^{18}$ Stunting usually describes the chronic nutritional status that delays the growth and development from the beginning of life. This condition is presented with a Z-score of height by age less than -2 SD based on the World Health Organization (WHO) growth standard. The effectiveness evaluation of stunting handling, which refers to the National Medium Term Development Plan (RPJMN) 2015-2019, indicated that stunting reduction efforts in Indonesia had exceeded the target from RPJMN. However, when referring to the international standards (WHO), the target has not yet been reached, so it must be more proactively pursued to achieve the lower target of stunting prevalence in accordance with the WHO standards. ${ }^{19}$

These results showed that children with very short stature have mothers with a high level of TSH. This condition indicates that the occurrence of hypothyroidism in the mother will affect the growth of the child. The results of this study can be used as evidence that the occurrence of hypothyroidism in mothers, especially those who were pregnant, should be treated immediately to reduce the incidence of stunting in Indonesia.

Diagnosis of hypothyroidism can be determined with thyroid tests, such as TSH, T3, T4, thyroid antibody blood tests, and the determination of iodine in urine, imaging tests, such as thyroid scans, ultrasound, or radioactive iodine absorption tests. ${ }^{20}$ Some limitations of this study were that hypothyroidism was only determined by TSH and T3 levels without anamneses, scanning, or other laboratory analyses. Also, the stunting diagnosis was made without laboratory analysis to determine the extent of the malnutrition in the examined children.

\section{Conclusion}

Here, we concluded that $3.2 \%$ of mothers were found with hypothyroidism, and $31.9 \%$ of children were identified with stunting in the Cangkringan subdistrict, and the hypothyroidism in the mothers is correlated with very short stature of their children. This research needs to be followed-up by efforts from staff members in Puskesmas and the government health officials to decrease the incidence of stunting and hypothyroidism, thus the community's welfare could be realized immediately and effectively.

\section{Acknowledgements}

We thank the General Director of Higher Education who funded this society empowerment project. We also would like thank all of the Biochemistry laboratory assistants, Ida Darojatun, Budi Lestari, Yuenleni, Dwi Nuh Riyadi, Yuswibowo, Nuryanto, and Sukamto, for their help during the research activity and laboratory analysis.

\section{Conflict of interests}

There is no conflict of interest among the authors.

\section{References}

1. Holland K. Everything you need to know about hypothyroidism [Internet]. Healthline; 2017 [updated 2017 April 3; cited 2020 Aug 29]. Available from: https://www.healthline.com/ health/hypothyroidism/symptoms-treatmentsmore.

2. Eastman CJ \& Zimmermann MB. The iodine deficiency disorders [Internet]. Chicago; 2017 [updated 2017 April 4; cited 2020 Aug 30]. Available from: https://www.thyroidmanager. org/.

3. Gaitan E and Dunn JT. Epidemiology of iodine 
deficiendy. Trend Endocrinol Metab. 1992; (5): 170-5.

4. Wibawa SW. Hipotiroid, dari Penyebab, Gejala hingga Pengobatannya [Internet]. Kompas.com; 2019 [cited 2021 Feb 26]. Available from: https://sains.kompas.com/ $\mathrm{read} / 2019 / 08 / 29 / 193600623 /$ hipotiroid-daripenyebab-gejala-hingga-pengobatannya

5. Chandra A. Prevalensi stunting in Epidemiologi stunting. 2020; 1: 10-26. Semarang: Universitas Diponegoro.

6. Setiaputri KA. Penilaian status gizi anak, cara mengukur hingga membaca hasilnya [Internet]. Jakarta: Hello Health Group Pte; 2020 [updated 2020 Oct 28; cited 2020 Aug 29]. Available from: https://hellosehat.com/parenting/nutrisi-anak/ penilaian-status-gizi-anak/\#gref.

7. National Institute of Diabetes and Digestive and Kidney Diseases. Hypothyroidism also called; Underactive thyroid [Internet]. United Stated: US Department of Health and Human Services National Institute of Health; 2019 [updated 2019 Nov 21; cited 2020 Aug 30]. Available from: https://medlineplus.gov/hypothyroidism.html.

8. Talaei A, Rafee N, Rafei F and A Chehrei. TSH cutoff point based on depression in hypothyroid patients. BMC Psychiatry. 2017; 17: 1-5.

9. IDAI. Kurva pertumbuhan WHO [Internet]. IDAl; 2020 [cited 2020 Aug 30]. Available from: https://.idai.or.id/professional-resources/kurvapertumbuhan-who

10. Viva. Angka Stunting di Indonesia Diharapkan Bisa Turun 14 Persen [Internet]. Jakarta: Suara Merdeka; 2020 [updated 2020 Aug 5; cited 2020 Aug 31]. Available from: https://www. suaramerdeka.com/news/nasional/237148angka-stunting-di-indonesia-diharapkan-bisaturun-14-persen.

11. Soewondo P and Cahyanur R. Penatalaksanaan penyakit-penyakit tiroid bagi dokter. Jakarta: Interna publishing, Hipotiroidisme dan gangguan akibat kekurangan iodium. 2018, 14-21.

12. Lowth M. Childhood and Congenital Hypothyroidism [Internet]. United Kingdom: Patient; 2014 [updated 2014 April 17; cited 2020 Aug 25]. Available from: https://patient. info/doctor/childhood-and-congenital- hypothyroidism.

13. National Institute of Diabtes and Digestive and Kidney Diseases. Neonatal hypothyroidism [Internet]. United States: US Department of Health and Human Services National Institute of Health; 2020 [updated 2020 Oct 8; cited 2020 Oct 30]. Available from: https://medlineplus. gov/hypothyroidism.html.

14. Cretinism (congenital hypothyroidism) [Internet]. [cited 2020 Aug 20]. Available from: https://congenitalhypothyroidism.weebly.com/ prevalence.html.

15. RS Awal Bros A. Yani. Kenali stunting dan cara pencegahannya [Internet]. Pekanbaru: RS Awal Bros. 2019 [cited 2020 Aug 31]. Available from: http://awalbros.com/anak/kenali-stunting-dancara-pencegahannya/\#.

16. Nareza M. Pahami penyebab stunting dan dampaknya pada kehidupan anak [Internet]. Jakarta: Alodokter; 2020 [updated 2020 Jan 30; cited 2020 Aug 31]. Available from: https:// www.alodokter.com/bayi-lahir-stunting-faktorpenyebab-dan-risiko.

17. Hidayati F. Memahami stunting pada anak [Internet]. Jakarta: Alodokter; 2019 [updated 2019 April 10; cited 2020 Aug 30]. Available from: https://www.alodokter.com/memahamistunting-pada-anak.

18. Humas Sardjito. Kenali penyebab stunting anak [Internet]. Yogyakarta: RSUP Dr. Sardjito; 2019 [updated 2019 July 22; cited 2020 Aug 30]. Available from: https://sardjito. co.id/2019/07/22/kenali-penyebab-stuntinganak/.

19. Kementerian Keuangan Republik Indonesia. Menko PMK: Target angka stunting di bawah 680 ribu per tahun [Internet]. Jakarta: Kementerian Keuangan Republik Indonesia; 2020 [updated 2020 Sept 14; cited 2020 Aug 29]. Available from: https://www.kemenkeu.go.id/publikasi/berita/ menko-pmk-target-angka-stunting-di-bawah680-ribu-per-tahun/.

20. McIntosh J. What is hypothyroidism? [Internet]. United Kingdom: Heatlhline Media UK Ltd; 2018 [updated 2018 Jan 2; cited 2020 Aug 20]. Available from: https://www.medicalnewstoday. com/articles/163729\#1. 